\title{
KEEFEKTIFAN PENGGUNAAN METODE PEMBELAJARAN TUTOR SEBAYA (PEER-TEACHING) DALAM KEMAMPUAN MEMBACA MEMAHAMI BAHASA JERMAN SISWA KELAS XI IPA SMA NEGERI 1 BONTONOMPO KABUPATEN GOWA
}

\author{
Nurmiati $^{1}$ dan Mantasiah ${ }^{2}$ \\ Fakultas Bahasa dan Sastra, Universitas Negeri Makassar \\ Email ${ }^{1}$ :nurmiykhadijah@gmail.com
}

\begin{abstract}
ABSTRAK
Penelitian ini dilakukan untuk memperoleh data dan informasi tentang kemampuan membaca memahami bahasa Jerman siswa. Penelitian ini merupakan Quasieksperimen.Populasi penelitian ini yaitu seluruh siswa kelas XI IPA SMA Negeri 1 Bontonompo Kabupaten Gowa yang terdiri dari 8 kelas.Untuk menentukan sampel teknik yang digunakan yaitu sampel acak (Random Sampling). Jumlah sampel adalah 2 kelas yaitu kelas XI IPA 1 dengan 27 siswa sebagai kelas eksperimen dan kelas XI IPA 2 dengan 27 siswa sebagai kelas kontrol. Data penelitian ini diperoleh melalui teks kemampuan membaca memahami. Data dianalisis menggunakan uji-t menunjukkan bahwa $t_{\text {hitung }} 14,5>t_{\text {tabel }} 2,007$. Hasil penelitian menunjukkan bahwa penggunaan metode pembelajaran tutor sebaya (Peer-Teaching) efektif dalam kemampuan membaca memahami bahasa Jerman siswa kelas XI IPA SMA Negeri 1 Bontonompo Kabupaten Gowa.
\end{abstract}

\section{Kata Kunci: Metode Tutor Sebaya (Peer-Teaching), Kemampuan Membaca, Bahasa Jerman.}

\begin{abstract}
This research was conducted to gain data and information about the students' reading ability in German. This research is a quasi-experimental research. The population of this research is students of XI IPA SMA Negeri 1 Bontonompo, Gowa, consisted of 8 classes. The researcher used a random sampling technique in deciding sample of the research. The samples were taken from two different classes namely Class XI IPA 1 consisted of 27 students as an experiment class and Class XI IPA 2 consisted of 27 students as a control class. The data from this research was gained from a reading ability test. The data was analyzed using $t$-test analysis showing that $t_{\text {count }} 14,5>t_{\text {table }} 2,007$. The result of study shows that the use of peer-teaching method is effective in improving students' language german reading ability in class XI IPA, SMA Negeri 1 Bontonompo, Gowa.
\end{abstract}

\section{Keywords: Peer-Teaching Method, Reading Ability, German Language}

\section{PENDAHULUAN}

Salah satu hakikat manusia adalah sebagai mahluk sosial yang dalam kehidupan sehari-hari menggunakan bahasa sebagai alat komunikasinya. Melalui bahasa manusia dapat menyampaikan segala aspirasi dan inspirasi yang dimiliki, dengan bahasa pula kita mampu mendistribusikan 
berbagai informasi kepada orang lain. Tujuan komunikasi itu sendiri dapat tercapai jika bahasa yang digunakan dapat dipahami dan dimengerti oleh lawan bicara.

Era globalisasi saat ini tidak dapat terelakkan lagi. Melalui berbagai media yang super canggih pertukaran informasi antarnegara sangatlah mudah.Berita dengan sangat cepat tersebar dan diterima dengan berbagai bahasa. Maka dari itu seseorang dituntut untuk mahir dalam menggunakan berbagai bahasa, tidak hanya sebatas kemahiran dalam penguasaan bahasa Indonesia sebagai bahasa nasional ataupun bahasa Inggris sebagai bahasa internasional, seseorang kini masih sangat perlu menguasai bahasa asing lainnya.

Salah satu bahasa asing yang memiliki banyak pengaruh di dunia ialah bahasa Jerman. Sebagian besar negara-negara di Eropa menjadikan bahasa Jerman sebagai bahasa nasionalnya. Di Indonesia bahasa Jerman telah diajarkan di sekolahsekolah secara formal pada jenjang pendidikan menengah seperti SMA/SMK dan MA.

$$
\text { Kemampuan membaca }
$$

memberikan konstribusi yang sangat besar dalam proses pembelajaran bahasa Jerman. Kegiatan belajar mengajar sering kali diperhadapkan pada teks-teks atau wacana berbahasa Jerman sehingga seseorang yang ingin menguasai suatu bahasa secara khususnya bahasa Jerman harus mahir dalam kemampuan membaca memahami.
Kemampuan membaca dalam kurikulum KTSP 2006 bahasa Jerman SMA kelas XI yang harus dicapai yaitu siswa mampu memahami wacana tulis berbentuk paparan atau dialog sederhana tentang kehidupan keluarga serta mampu mengetahui bentuk dan tema wacana sederhana secara tepat dan memperoleh informasi umum.

Berdasarkan hasil observasi awal pada siswa-siswa SMA Negeri 1 Bontonompo melalui wawancara langsung dengan guru mata pelajaran bahasa Jerman, banyak siswa yang mengalami kesulitan dalam kemampuan membaca, seperti memahami isi/ide pokok serta menemukan informasi penting pada teks yang dibaca. Beberapa faktor yang menyebabkan antara lain, bahasa Jerman merupakan bahasa yang baru diperkenalkan di tingkat SMA, proses pengajaran yang masih menggunakan metode ceramah dan diskusi tanpa adanya variasi pengajaran kemampuan membaca memahami itu sendiri dan guru cenderung lebih banyak memusatkan pada struktur kalimat atau materi yang tersaji dalam buku. Adapun nilai yang dicapai oleh siswa kelas XI ratarata hanya 65 pada bulan juli tahun 2016, sedangkan nilai KKM di SMA Negeri 1 Bontonompo adalah 75.

Salah satu metode yang dapat diaplikasikan untuk kemampuan membaca adalah metode pembelajaran Peer-Teaching atau biasa dikenal dengan istilah tutor sebaya. Metode Peer-Teaching 
merupakan suatu pembelajaran yang dilakukan dengan cara memperdayakan kemampuan siswa yang memiliki daya serap yang tinggi. Siswa tersebut mengajarkan materi atau latihan kepada temantemannya yang belum paham atau memiliki daya serap yang rendah. Pembelajaran ini mempunyai kelebihan ganda yaitu siswa yang mendapat bantuan lebih efektif dalam menerima materi sedangkan bagi tutor merupakan kesempatan untuk mengembangkan kemampuan diri. Peran guru disini adalah mengawasi kelancaran pelaksanaan metode ini dengan memberikan pengarahan dan sebagainya.

\section{METODE PEMBELAJARAN PEER-TEACHING}

Salah satu tipe pembelajaran kooperatif adalah tipe tutor sebaya atau Peer-Teaching. Pada proses pembelajaran metode PeerTeaching, siswa yang akan berperan sebagai tutor terlebih dahulu dibekali materi yang akan disampaikan oleh guru. Pembekalan ini disampaikan didalam maupun diluar jam pelajaran, tetapi dalam pembelajaran berlangsung guru juga menerangkan materi pokok bahasan. Dalam kegiatan diskusi siswa yang ditunjuk sebagai tutor bertugas menjelaskan dan membantu siswa yang mengalami kesulitan yang sebelumnya sudah mendapatkan pelajaran secara khusus.
Tutor sebaya atau Peer-Teaching merupakan suatu pembelajaran yang dilakukan dengan cara memperdayakan kemampuan siswa yang memiliki daya serap yang tinggi. Siswa tersebut mengajarkan materi atau latihan kepada temantemannya yang belum paham atau memiliki daya serap yang rendah. Pembelajaran ini mempunyai kelebihan ganda yaitu siswa yang mendapat bantuan lebih efektif dalam menerima materi. Sedangkan bagi tutor merupakan kesempatan untuk mengembangkan kemampuan diri. Peran guru disini adalah mengawasi kelancaran pelaksanaan metode ini dengan memberikan pengarahan dan sebagainya.

\begin{tabular}{lcrr}
\multicolumn{2}{c}{ Konsep } & \multicolumn{2}{r}{ Peer-Teaching } \\
secara & umum & dapat diartikan \\
sebagai & proses yang melibatkan
\end{tabular} seseorang untuk memberikan bantuan dan bimbingan belajar kepada orang lain dalam kegiatan pembelajaran. Dengan kata lain, konsep Peer-Teaching adalah kegiatan mengajar yang mencakup bimbingan dan bantuan belajar perseorangan atau kelompok.

Menurut Ahmadi \& Supriyono (2004:184) tutor adalah siswa yang sebaya yang ditunjuk atau ditugaskan membantu temannya yang mengalami kesulitan belajar, karena hubungan antara teman sebaya umumnya lebih dekat dibandingkan hubungan guru-siswa.

Penerapan metode tutor sebaya atau Peer-Teaching pada mulanya 
bertujuan untuk memberikan bimbingan belajar bagi siswa yang mengalami kesulitan belajar. Pada perkembangan dunia pendidikan seperti saat ini metode tutor sebaya atau Peer-Teaching mulai diterapkan di beberapa sekolah dengan tujuan untuk menarik perhatian siswa sehingga prestasi belajar meningkat.

Menurut Anas (2014:66) tujuan tutor sebaya atau Peer-Teaching adalah: 1) untuk meningkatkan penguasaan pengetahuan para siswa sesuai dengan yang dimuat dalam tujuan pembelajaran; 2) meningkatkan kemampuan dan keterampilan atau hambatan agar mampu membimbing diri sendiri; 3) meningkatkan kemampuan siswa tentang cara belajar mandiri dan menerapkannya pada masing-masing bahan pelajaran yang dipelajari.

Secara umum prinsip-prinsip yang harus diperhatikan dalam strategi pembelajaran aktif yang diturunkan dari prinsip belajar menurut Sumantri dan Permana (2001:101-102) adalah: 1) seorang murid harus belajar sendiri tanpa adanya bantuan dari orang lain; 2) setiap murid belajar menurut tempo (kecepatan sendiri dan setiap kelompok umur terdapat variasi dalam kecepatan belajar); 3) seorang murid lebih termotivasi apabila ia diberikan tanggung jawab untuk belajar sendiri".

Terdapat beberapa hal yang harus diperhatikan dalam penerapan metode tutor sebaya seperti yang diutarakan Saminanto (2010:48) adalah sebagai berikut: 1) pilihlah materi dan bagi dalam sub-sub materi; 1) guru membentuk kelompok siswa secara heterogen sebanyak sub-sub materi. Siswa yang pandai tersebar dalam setiap kelompok dan bertindak sebagai tutor sebaya; 3) masing-masing kelompok mempelajari materi itu dengan dipandu siswa yang pandai; 4) memberikan waktu yang cukup untuk persiapan baik di dalam kelas maupun luar kelas; 5) setiap kelompok melalui wakilnya menyampaikan sub materi sesuai dengan tugas yang telah diberikan. Guru tetap sebagai narasumber; (6) memberikan kesimpulan.

\section{METODE PENELITIAN}

Penelitian ini menggunakan dua variabel yaitu variabel bebas $(\mathrm{X})$ dan variabel terikat $(\mathrm{Y})$. Variabel bebas yang dimaksud adalah metode pembelajaran tutor sebaya (PeerTeaching) dan variabel terikat adalah kemampuan membaca memahami bahasa Jerman Siswa Kelas XI IPA Negeri 1 Bontonompo.

Desain penelitian yang digunakan adalah Quasi experimental design (eksperimental-semu)Non equivalent control group. Dalam penelitian ini melibatkan dua kelompok yaitu kelas eksperimen yang menggunakan metode pembelajaran tutor sebaya atau Peer-Teaching dan kelas kontrol menggunakan metode konvensional dalam pembelajaran kemampuan membaca memahami bahasa Jerman 
siswa kelas XI IPA SMA Negeri 1 Bontonompo.

Populasi dalam penelitian ini adalah seluruh siswa kelas XI IPA SMA Negeri 1 Bontonompo yang terdiri dari 8 kelas dengan jumlah siswa 300 orang. Sampel penelitian adalah siswa kelas XI IPA 1 yang berjumlah 27 siswa sebagai kelas eksperimen dan kelas XI IPA 2 yang berjumlah 27 siswa sebagai kelas kontrol, yang dipilih secara acak (Random Sampling).

Teknik pengumpulan data yang digunakan dalam penelitian ini dilakukan melalui tes kemampuan membaca memahami bahasa Jerman.

\section{Tes awal (Pre-test)}

Pada tahap ini peneliti menentukan dua kelas sebagai sampel penelitian yaitu kelas ekperimen dan kontrol.Kedua kelas tersebut kemudian mengikuti pre-test untuk mengukur kemampuan awal siswa dalam kemampuan membaca memahami sebelum diberikan perlakuan (treatment).

\section{Tes Akhir (Post-test)}

Setelah diberikan perlakuan selanjutnya siswa akan diberikan post-test berupa tes untuk mengukur kemampuan membaca memahami siswa pada kelas eksperimen dan kelas kontrol. Kegiatan ini bertujuan untuk melihat perbedaan kemampuan membaca memahami siswa setelah diberikan treatment serta bertujuan untuk melihat perbandingan nilai yang dicapai pada saat pre-test, apakah metode pembelajaran tutor sebaya ini efektif.
Analisis data dalam penelitian ini menggunakan analisis statistik inferensial. Analisis statistik inferensial untuk menguji hipotesis dengan menggunakan analisis uji-t. Sebelum menguji hipotesis, terlebih dahulu menghitung rata-rata, varians dan simpangan baku. Setelah itu, data tersebut diuji normalitasnya dan homogenitas.

\section{PEMBAHASAN}

Pada bagian ini dibahas tentang hasil yang diperoleh dari analisis data penelitian tentang keefektifan metode pembelajaran Tutor Sebaya (PeerTeaching) dalam kemampuan membaca memahami siswa kelas XI IPA SMA Negeri 1 Bontonompo. Perolehan skor yang telah dipaparkan sebelumnya memberikan gambaran bahwa terdapat perolehan skor siswa yang menggunakan metode tutor sebaya (peer-teaching) lebih tinggi dibandingkan dengan kelompok siswa yang tidak menggunakan metode tutor sebaya (peer-teaching) pada pembelajaran kemampuan membaca memahami bahasa Jerman siswa kelas XI IPA SMA Negeri 1 Bontonompo.

Dalam penelitian ini, pembelajaran dilakukan selama 4 kali pertemuan setelah pemberian pre-test di masing-masing kelas.Pada kelas eksperimen diajar dengan menggunakan metode pembelajaran Tutor Sebaya (Peer-Teaching), sementara di kelas kontrol diajar tanpa menggunakan metode pembelajaran Tutor Sebaya (PeerTeaching). Tema yang dipelajari 
selama 4 kali pembelajaran yaitu die Familie. Berikut ini adalah kegiatan siswa kelas eksperimen selama empat kali petemuan:

1. Pertemuan I, peneliti memilih tutor dengan bantuan guru mata pelajaran. Setelah itu, siswa dibagi menjadi beberapa kelompok kecil. Masing-masing kelompok memiliki tutor. Pada pertemuan ini peneliti membagikan teks tentang wawancara antara teman yang di dalamnya terdapat latihan bagaimana siswa dapat memahami isi teks tersebut dan mengerjakan latihan yang diberikan. Tugas seorang tutor disini yaitu, membantu siswa yang mendapatkan kesulitan dalam proses pembelajaran tidak hanya dalam kelas melainkan diluar kelas juga.

2. Pertemuan II, pada pertemuan ini siswa tetap dibagi dalam kelompok yang telah ditentukan pada pertemuan sebelumnya. Hal ini dilakukan agar siswa merasa nyaman dan kerja sama dalam kelompok dapat lebih kompak. Materi yang dipelajari pada pertemuan ini tentang possesivpronomen (kata ganti kepunyaan).

3. Pertemuan III, siswa mempelajari tentang melengkapi pohon keluarga secara berkelompok seperti pertemuan sebelumnya. Pada pertemuan ini peneliti tidak hanya melatih kemampuan membaca memahami siswa melainkan peneliti juga melatih bagaimana menceritakan keluarga mereka. Hal ini dilakukan agar siswa tidak merasa jenuh dengan pembelajaran yang monoton.

4. Pertemuan IV, seperti pertemuan sebelumnya siswa diberikan soal dan dikerjakan secara berkelompok dengan tutor masingmasing. Pada pertemuan ini siswa semakin kompak dalam melakukan proses pembelajaran secara berkelompok. Setiap pertemuan dilakukan evaluasi secara bersamasama dengan tujuan mengetahui sejauh mana siswa memahami materi yang telah diberikan.

Setelah diberikan treatment dengan metode pembelajaran tutor sebaya (Peer-Teaching) siswa lebih aktif dalam proses pembelajaran. Hal ini dipengaruhi oleh kebiasaan pada saat treatment yaitu siswa melakukan diskusi bersama teman kelompok.

Hasil pre-test menunjukkan bahwa nilai rata-rata (mean) skorkemampuan membaca memahami siswa kelas XI IPA 1 sebagai kelas eksperimen adalah 60,44 masih dalam kategori belum memenuhi standar kelulusan (75) dan nilai kemampuan membaca memahami siswa kelas XI IPA 2 sebagai kelas kontrol adalah 37,033 juga masih tergolong dalam kategori belum memenuhi standar kelulusan (75).

Hasil uji normalitas pada data pretest kedua kelas dinyatakan normal sebab data pre-test kedua kelas tersebut menunjukkan bahwa kelas eksperimen dan kelas kontrol memiliki Chi Kuadrat hitung yang 
masing-masing lebih kecil dari nilai tabel Chi Kuadrat yaitu untuk kelas eksperimen $X_{\text {hitung }}^{2}<X_{\text {tabel }}^{2}(-64,72<$ 11,070). Kemudian hasil uji homogenitas pre-test menunjukkan bahwa nilai $F_{\text {hitung }}<F_{\text {tabel }}(2,069<$ $5,05)$ sehingga kedua data sampel tersebut dinyatakan homogen.

Hasil post-test siswa yang diajar dengan menggunakan metode pembelajaran tutor sebaya (PeerTeaching) menunjukkan adanya peningkatan nilai yang signifikan dari nilai tes sebelumnya atau pre-test. Siswa memperoleh nilai dengan ratarata (mean) skor89,85. Dengan adanya pencapaian angka-angka tersebut berdasarkan indikator pada rencana pelaksanaan pembelajaran, siswa yang mampu menjawab soal instrument dengan benar diuraikan sebagai berikut. Dari 27 siswa yang mampu menjawab semua soal dengan benar pada bagian I yaitu soal pilihan benar atau salah yang terdiri dari 10 butir soal adalah 15 siswa (lampiran 8 hal 106), pada soal bagian II yaitu soal pilihan ganda yang terdiri dari 10 butir soal yang mampu menjawab benar semua adalah 4 siswa (lampiran 8 hal 106), pada soal bagian III yaitu soal melengkapi pohon keluarga yang terdiri dari 10 butir soal yang mampu menjawab benar semua adalah 25 siswa (lampiran 8 hal 106), pada soal bagian IV yaitu soal pilihan benar atau salah yang terdiri dari 10 butir soal yang mampu menjawab benar semua adalah 10 siswa (lampiran 8 hal 106), dan pada soal bagian $\mathrm{V}$ yaitu soal pilihan ganda yang terdiri dari 10 butir soal yang mampu menjawab benar semua adalah 9 siswa (lampiran 8 hal 106). Dengan banyaknya siswa yang menjawab benar, maka siswa mampu memahami teks atau wacana dengan tepat.

Sedangkan siswa yang tidak diajar dengan menggunakan metode pembelajaran tutor sebaya (PeerTeaching) menunjukkan perolehan nilai siswa tidak mengalami peningkatan yang signifikan. Hal itu dapat dilihat dari perolehan nilai ratarata (mean) skor61,19. Dengan demikian, nilai rata-rata (mean) skor kelas eksperimen lebih besar daripada nilai rata-rata (mean) skor kelas kontrol.

Hasil akhir dari penelitian ini dilakukan dengan menggunakan uji-t untuk menguji hipotesis. Kelas ekperimen dan kelas kontrol diuji dengan menggunakan rumus yang sama. Hasilnya adalah $\mathrm{t}$ hitung kelas eksperimen $=14,5$ sementara $\mathrm{t}$ tabel $=$ 2,007, jadi $\mathrm{t}$ hitung $>\mathrm{t}$ tabel $(14,5>$ 2,007). Oleh karena itu, $\mathrm{H}_{1}$ yang menyatakan penggunaan metode pembelajaran tutor sebaya (PeerTeaching) efektif dalam kemampuan membaca memahami bahasa Jerman dinyatakan berhasil dan $\mathrm{H}_{0}$ yang menyatakan penggunaan metode pembelajaran tutor sebaya (PeerTeaching) tidak efektif dalam kemampuan membaca memahami bahasa Jerman dinyatakan ditolak. Sehingga dapat disimpulkan bahwa penelitian tentang keefektifan penggunaan metode pembelajaran tutor sebaya (Peer-Teaching) dalam 
kemampuan membaca memahami bahasa Jerman siswa kelas XI IPA SMA Negeri 1 Bontonompo Kabupaten Gowa, dinyatakan berhasil. Uji t memiliki hasil yang tinggi karena berdasarkan pengujian hipotesis yang mendapatkan hasil tinggi.Nilai yang di dapatkan siswa sebagian besar tinggi, jadi hasil perolehan $t_{\text {hitung }}$ tinggi.

Berdasarkan uraian tersebut dapat disimpulkan bahwa penggunaan metode pembelajaran tutor sebaya (Peer-Teaching) baik digunakan. Hal ini dinyatakan berdasarkan hasil penelitian yang menunjukkan bahwa kemampuan membaca memahami siswa meningkat.Pernyataan tersebut didukung dan diperkuat berdasarkan hasil perhitungan tes. Perbandingan hasil kemampuan pre-test dan posttest menunjukkan nilai $\mathrm{t}$ hitung $>$ nilai $\mathrm{t}$ tabel.Hal ini menunjukkan bahwa hipotesis penelitian yang diajukan diterima.

\section{KESIMPULAN}

Berdasarkan hasil uraian data yang telah diuraikan pada bab IV, dapat disimpulkan bahwa penggunaan metode pembelajaran tutor sebaya mempunyai pengaruh positif yang signifikan terhadap kemampuan membaca memahami bahasa Jerman siswa kelas XI IPA SMA Negeri 1 Bontonompo Kabupaten Gowa. Hal tersebut dapat dibuktikan dengan hasil analisis data yang telah dilakukan, dengan nilai post-test siswa setelah dilakukan uji-t pada masing-masing kelompok dengan hasil analisis data yaitu $t_{\text {hitung }}=14,5>$ $\mathrm{t}_{\text {tabel }}=2,007$ pada taraf signifikan 0,05 yang berarti bahwa metode pembelajaran tutor sebaya (PeerTeaching) efektif dalam kemampuan membaca memahami bahasa Jerman siswa kelas XI IPA SMA Negeri 1 Bontonompo Kabupaten Gowa. Berdasarkan hasil analisis data tersebut, maka $\mathrm{H}_{1}$ dinyatakan diterima dan $\mathrm{H}_{0}$ dinyatakan ditolak. Oleh karena $\mathrm{H}_{1}$ diterima, maka penelitian ini dinyatakan berhasil.

\section{DAFTAR PUSTAKA}

Abidin, Yunus. 2012. Pembelajaran Membaca Berbasis

Pendidikan Karakter, Bandung: PT. Refika Aditama.

Ahmadi, Abu \& Supriyono, Widodo. 2004. Psikologi Belajar. Jakarta: PT. Rineka Cipta.

Anas, Muhammad. 2014. Mengenai Metode Pembelajaran. Pasuruan: CV. Pustaka Hulwa.

Arikunto, Suharsimi. 2000. Pengelolaan Kelas dan Siswa. Jakarta:Rajawali.

Dalman. 2013. Keterampilan Membaca. Jakarta: PT. RajaGrafindo Persada.

Drowdowski, Günter. 1983. Deutscher Universel Wörterbuch

Bibliographisches Institut. Wien, Zürich: Duden Verlag.

Saddhono, Kundharu dan Slamet. 2012. Meningkatkan 
Keterampilan Berbahasa

Indonesia (Teori dan

Aplikasi). Bandung: Karya

Putra Darwati.

Saminanto. 2010. PTK. Semarang:

RaSAIL Media Group.

Sumantri, Mulyani dan Permana,

Johar. 2001. Startegi

Belajar Mengajar.

Bandung: C.V Maulana.

Tarigan, Henry Guntur. 2008.

Membaca Sebagai Suatu

Keterampilan Berbahasa.

Bandung: Angkasa. 